\title{
PENERAPAN METODE TUNJUKKAN DAN CERITAKAN TERHADAP KESIAPAN MEMBACA PADA ANAK TK
}

\author{
Christina $^{1}$, Sri Tiatri ${ }^{2}$, Pamela Hendra Heng ${ }^{3}$ \\ ${ }^{1}$ Program Studi Magister Psikologi, Universitas Tarumanagara, Jakarta \\ Email: christinkytin@gmail.com \\ ${ }^{2}$ Fakultas Psikologi, Universitas Tarumanagara, Jakarta \\ Email: : sri.tiatri@untar.ac.id \\ ${ }^{3}$ Fakultas Psikologi, Universitas Tarumanagara, Jakarta \\ Email: pamelah@fpsi.untar.ac.id
}

\begin{abstract}
Reading readiness is one of the skills given to early childhood through playing while learning. Kindergarten children are given assignments in the form of worksheets and the teacher will ask those children to read and then mention the words back on their worksheet. If the learning system to read like this were practiced repeatedly, the child will get bored. Reading readiness can be done through telling stories and using flash cards. One of the behaviors that show the child is in the reading readiness stage is when a child who is able to use spoken language to express an object. This can be realized through the show and tell method, which is a method that provides opportunities for children to learn new things through storytelling and listening to stories from their friends. This study aims to see the application of the show and tell method on reading readiness of kindergarten children. Participants in this study were 16 TK B students in PAUD FL which were divided into two groups, namely EG (Experiment Group) and CG (Control Group). Participants will be provided with an adapted Reading Readiness Assessment test kit and an Expressive Vocabulary Test as additional analysis given at the beginning and end of the study. The data analysis used an independent sample $t$-test which resulted that the method show and tell was ineffective for the reading readiness of kindergarten children $(t=1,678 ; p=0.114)$ but the method show and tell was effective in increasing the number of children's word to describe something $(t=4.961 ; p=0.001)$ and children's vocabulary $(t=4,797 ; p=0.002)$.
\end{abstract}

Keywords: Reading readiness, show and tell method, storytelling, vocabulary

\begin{abstract}
ABSTRAK
Kesiapan membaca merupakan salah satu keterampilan yang diberikan kepada anak usia dini melalui kegiatan bermain sambil belajar. Anak TK diberikan tugas dalam bentuk lembar kerja dan meminta anak untuk membaca lalu menuliskan kembali kata yang ada pada lembar kerja tersebut. Apabila sistem belajar membaca seperti ini dilakukan berulang, maka anak akan merasa jenuh. Kesiapan membaca dapat dilakukan dengan cara bercerita, mendongeng dan penggunaan media flash card. Salah satu perilaku yang menunjukkan anak berada dalam tahap kesiapan membaca adalah anak mampu menggunakan bahasa lisan untuk menceritakan suatu objek. Hal ini dapat diwujudkan dalam metode tunjukkan dan ceritakan, yaitu metode yang memberikan peluang bagi anak untuk belajar hal baru melalui kegiatan bercerita dan mendengarkan cerita teman sekelompoknya. Penelitian ini bertujuan untuk melihat efektivitas penerapan metode tunjukkan dan ceritakan terhadap kesiapan membaca anak TK. Partisipan pada penelitian ini adalah 16 murid TK B di PAUD FL yang dibagi menjadi dua kelompok, yaitu KE (Kelompok Eksperimen) dan KK (Kelompok Kontrol). Partisipan akan diberikan alat tes Reading Readiness Assessment yang telah diadaptasi serta Expressive Vocabulary Test sebagai analisis tambahan yang diberikan pada awal dan akhir penelitian. Analisis data menggunakan uji beda yang menunjukkan hasil bahwa metode tunjukkan dan ceritakan tidak efektif terhadap kesiapan membaca anak TK $(\mathrm{t}=1.678 ; \mathrm{p}=0.114)$ namun metode tunjukkan dan ceritakan efektif untuk meningkatkan jumlah kata anak $(\mathrm{t}=4.961 ; \mathrm{p}=0.001)$ dan jumlah kosakata anak $(\mathrm{t}=4.797 ; \mathrm{p}=0.002)$.
\end{abstract}

Kata Kunci: Kesiapan membaca, metode tunjukkan dan ceritakan, bercerita, kosakata

\section{PENDAHULUAN}

\section{Latar Belakang}

Pendidikan Anak Usia Dini (PAUD) merupakan masa pendidikan paling mendasar yang mencakup enam aspek perkembangan, yaitu aspek perkembangan nilai agama dan moral, motorik, kognisi, sosial, bahasa dan seni (Kemendikbud, 2015; Slavin, 2009). Keterampilan bahasa adalah 
salah satu keterampilan yang dibutuhkan anak untuk berhasil dalam lingkungan sekolah serta kehidupan sehari-hari (Morrison, 2008). Membaca merupakan salah satu keterampilan bahasa yang dapat dipelajari sejak anak berada di jenjang pendidikan Taman Kanak-Kanak (TK). Belajar membaca untuk anak TK merupakan hal yang sangat penting sebagai tujuan persiapan membaca yang akan membuat anak berhasil dalam membaca (Robbins, 1978; Susanto, 2011). Kesiapan membaca sebagai sebuah proses untuk mengubah simbol yang dicetak ke dalam bentuk suara (Mason, 1997). Kegiatan kesiapan membaca ini tepat diberikan kepada anak yang berusia 5-6 tahun atau anak TK. Oleh sebab itu, maka anak-anak TK sebaiknya dimasukkan ke dalam suatu program kesiapan membaca. Tujuan akhir dari kemampuan membaca adalah anak-anak diharapkan mampu menunjukkan performanya dalam memahami bacaan, sehingga mereka memiliki cara yang tepat untuk menampilkan keterampilan bahasanya secara lisan maupun tulisan (Tiatri, 2009).

Idealnya keterampilan membaca, menulis, dan berhitung bukanlah tujuan utama pembelajaran di TK. Namun, Eliza (2014) menyatakan keadaan yang bertolak belakang bahwa telah terjadi pergeseran tanggung jawab dalam proses pembelajaran antara guru SD (Sekolah Dasar) dengan guru TK (Taman Kanak-kanak) baik secara implisit dan juga eksplisit. Belajar membaca dilakukan di TK dengan cara guru memberikan tugas kepada anak dalam bentuk lembar kerja, lalu meminta anak untuk membaca lalu menuliskan kembali kata yang ada pada lembar kerja tersebut (Juwita \& Tasu'ah, 2015). Sementara mendengarkan cerita dianggap hanya sebagai permainan saja dan bukan menjadi bagian dalam kurikulum pembelajaran (Karweit, 1989). Apabila sistem belajar membaca seperti ini dilakukan berulang, maka anak akan merasa tertekan dan juga merasa jenuh. Hal ini disebabkan karena berdasarkan perkembangan usia, anak TK seharusnya berada dalam dunia bermain sambil belajar (Juwita \& Tasu'ah, 2015).

Robbins (1978) dan Miller (dalam Dhieni et al., 2009) menjelaskan beberapa keterampilan yang diperlukan dan harus diajarkan kepada anak sebelum anak mulai membaca, yaitu keterampilan auditori, keterampilan visual-motorik, keterampilan bahasa dan keterampilan konseptual. Keterampilan auditori adalah keterampilan anak untuk membedakan suara kata-kata/diskriminasi pendengaran suara selama tahun-tahun awal dan akan berkembang dengan baik pada usia lima tahun. Diskriminasi pendengaran suara bahasa merupakan proses dasar membaca, sehingga anak mampu memperhatikan suara secara terpisah dalam kata-kata yang diucapkan dan mengidentifikasi makna suara tersebut. Kesadaran fonologis merupakan bagian dari keterampilan auditori yang juga menjadi predictor kuat untuk melihat keberhasilan membaca anak (McNamara et al., 2004). Oleh sebab itu, hampir semua tes kesiapan membaca melibatkan bagian persepsi pendengaran.

Keterampilan visual-motorik adalah keterampilan ini dihubungkan dengan koordinasi otot okular yang berfungsi untuk menggerakan bola mata untuk menemukan objek tertentu. Terkait dengan membaca maka otot okular diperlukan untuk melihat bentuk dan huruf tunggal maupun kelompok. Ketika membaca maka anak harus mampu mengarahkan mata mereka pada huruf-huruf dan menggerakkan mata mereka dari kiri ke kanan melintasi kelompok-kelompok huruf. Diskriminasi visual-motorik diwujudkan dalam bentuk kemampuan untuk mencocokkan huruf, membedakan warna, bentuk, serta kemampuan untuk menyalin huruf dan kata (Robbins, 1978).

Keterampilan bahasa, berupa bahasa lisan dan tulisan adalah dasar untuk membaca. Bahasa dapat membatasi dan memperluas kemampuan anak untuk menghadapi lingkungan mereka. Bahasa lisan adalah alat yang digunakan untuk memberi label dan menjelaskan lingkungan. Bahasa cetak adalah alat lain yang diajarkan kepada anak sehingga mereka dapat memberi label dan menjelaskan 
pengalaman mereka melalui tulisan. Miller (dalam Dhieni et al., 2009) menambahkan bahwa kemampuan bahasa lisan yaitu berbicara dan mendengarkan merupakan komponen penting dalam pembelajaran membaca. Kemampuan ini meliputi kemampuan untuk mengingat, mengikuti petunjuk, menceritakan objek atau peristiwa tertentu, menjelaskan dengan sederhana pendapat anak dan juga menjadi sarana untuk anak mengekspresikan perasaan yang dimilikinya.

Keterampilan konseptual melibatkan kemampuan untuk membayangkan ide-ide abstrak yang digeneralisasi dari contoh-contoh tertentu. Kemampuan untuk dikonseptualisasikan adalah proses perkembangan kognitif. Membaca kata "apel" berarti seseorang dapat membayangkan objek secara konseptual, warnanya, bentuknya, ukurannya, kegunaannya, dan mungkin pengalaman sebelumnya dengan apel.

McNamara et al. (2004) membagi kesiapan membaca menjadi empat kategori, yaitu phoneme identities, rhyming words, phoneme blending dan lower case/upper case letter name knowledge. Pada kategori phoneme identities, anak diminta untuk mendengarkan kalimat yang memiliki dua kata yang serupa dalam struktur fonetiknya. Rhyming words merupakan kemampuan untuk mengenali kata-kata dengan rima tertentu. Pada kategori ini anak diminta untuk mendengarkan dua kata lalu anak harus mampu menyatakan apakah pasangan kata tersebut memiliki rima yang sama atau tidak. Phoneme blending merupakan kategori untuk menilai kemampuan anak dalam hal mensintesis informasi fonologis yang diterima berupa huruf/alfabet. Pada kategori ini anak diminta untuk mendengarkan peneliti mengatakan serangkaian fonem individu dalam interval satu detik. Anak kemudian diminta untuk menggabungkan suara-suara ini menjadi kata-kata. Anak dinilai benar jika mereka berhasil memadukan fonem yang relevan. Lower-case and upper-case letter name knowledge merupakan kemampuan anak untuk menyebutkan 26 huruf kapital dan kecil. Anak akan diberikan nilai atau skor, jika ia mampu memberikan respons yang benar terkait dengan huruf-huruf yang tersedia.

Pengenalan konsep membaca pada anak usia dini dapat dilakukan dengan kegiatan yang sesuai dengan karakteristik dan kebutuhan anak, yaitu bermain sambil belajar. Kegiatan yang dimaksud dapat berupa mendongeng, mengobrol atau bercerita, menggunakan flash card dan membaca cerita bersama. Kegiatan tersebut dapat membuat anak berada dalam lingkungan kesiapan membaca (Eliza, 2014; Juwita \& Tasu'ah, 2015). Tzu (dalam Susanto, 2011) menyatakan bahwa kesiapan membaca dapat diidentifikasi dari berbagai perilaku yang diperlihatkan pada anak, seperti adanya rasa ingin tahu anak tentang benda-benda di lingkungan sekitar; anak mampu mengidentifikasi sebuah gambar; serta mampu berkomunikasi lisan dalam bentuk kalimat.

Perilaku yang disebutkan di atas merupakan perilaku yang dibutuhkan dalam menerapkan metode tunjukkan dan ceritakan. Metode tunjukkan dan ceritakan berupa presentasi mengenai objek atau pengalaman dalam kehidupan nyata (Bangun, 2018). Metode ini membuka peluang anak untuk belajar hal baru melalui cerita temannya serta anak juga akan membagikan cerita tentang suatu objek sesuai dengan pemahaman dan pembelajarannya. Oleh sebab itu, keterampilan bicara lisan dan menyimak atau mendengarkan anak akan berkembang melalui metode tunjukkan dan ceritakan.

Keterampilan bicara lisan dapat diwujudkan dalam bentuk bercerita, karena cerita adalah kegiatan yang menarik bagi anak serta memberikan kesempatan kepada anak untuk mengembangkan penggunaan bahasa dan pemahaman bahasa. Cerita juga dapat meningkatkan motivasi anak untuk belajar membaca, karena apa yang terkandung di dalam cerita merupakan hal-hal yang menarik dan juga bermakna bagi anak-anak (Karweit, 1989). Kegiatan menyimak atau mendengarkan 
merupakan kegiatan yang sangat penting bagi perkembangan bahasa. Melalui mendengar, anak mampu menyimpan berbagai informasi untuk menyelesaikan tugas-tugasnya di sekolah. Bercerita juga merupakan contoh kegiatan untuk meningkatkan kemampuan menyimak atau mendengarkan (Bowyer-Crane et al., 2008).

Metode tunjukkan dan ceritakan dilihat mampu meningkatkan kemampuan berbicara ekspresif yang mampu memantau penggunaan kosakata dan tata bahasa anak serta mendorong anak untuk menjawab pertanyaan dan mencari informasi dengan mengajukan pertanyaan (Bowyer-Crane et al., 2008). Dickinson dan McCabe (2001) menambahkan bahwa keterampilan kosakata dan tata bahasa yang merupakan dua kemampuan dasar yang mampu mengukur kemampuan membaca. Oleh sebab itu metode tunjukkan dan ceritakan dilakukan untuk memantau penggunaan kosakata dan tata bahasa anak yang merupakan dua kemampuan dasar yang mampu memprediksi kemampuan membaca (Bowyer-Crane, et al., 2008; Dickinson \& McCabe, 2001).

Namun hingga saat ini belum ada hasil penelitian yang menunjukkan pengaruh langsung antara penerapan metode tunjukkan dan ceritakan terhadap keterampilan membaca anak. Sebaliknya, hasil penelitian dari Endarweni (2014); Bangun (2018); dan Suryaningsih (2017) menunjukkan bahwa metode tunjukkan dan ceritakan terbukti mampu meningkatkan kemampuan berbicara lisan siswa. Pentingnya bahasa lisan dalam kaitannya dengan membaca secara signifikan dicatat dalam sebuah studi oleh Loban (dalam Robbins, 1978).

Berdasarkan pemaparan di atas, maka metode tunjukkan dan ceritakan merupakan program yang berfokus pada bahasa lisan yang mampu meningkatkan keterampilan bahasa bahasa ekspresif, yaitu berbicara. Namun belum ada hasil penelitian yang menunjukkan bahwa tunjukkan dan ceritakan mampu meningkatkan kesiapan membaca pada anak, padahal kemampuan berbicara yang tinggi mampu menunjukkan kemampuan membaca anak. Oleh sebab itu, peneliti tertarik meneliti tentang efektivitas metode tunjukkan dan ceritakan terhadap kesiapan membaca anak TK.

\section{Rumusan Masalah}

"Apakah penerapan metode tunjukkan dan ceritakan efektif terhadap kesiapan membaca anak Taman Kanak-Kanak (TK)?”

\section{METODE PENELITIAN}

\section{Partisipan dan Prosedur Penelitian}

Penelitian ini dilakukan dengan metode kuasi eksperimen dengan desain kelompok ( group design) yang melihat pada nilai skor rata-rata (mean) dari variabel terkait yang sedang diteliti. Penelitian ini menggunakan pendekatan kuantitatif dengan menggunakan teknik analisis data uji beda, untuk gain score dari post-test dan pre-test yang kemudian akan dibandingkan pada dua kelompok, yaitu kelompok eksperimen (KE) dan kelompok kontrol (KK).

Desain reversal yang digunakan dalam penelitian ini adalah desain A-B-A yang merupakan pengembangan dari desain A-B. Awalnya target perilaku diukur secara berkelanjutan pada kondisi baseline (A1) dengan periode waktu tertentu lalu dilakukan kondisi intervensi (B). Setelah itu peneliti melakukan pengukuran pada kondisi baseline kedua (A2) sebagai kontrol untuk fase intervensi, sehingga memungkinkan peneliti menarik kesimpulan tentang hubungan antara variabel bebas dengan variabel terikat. 
Partisipan dalam penelitian ini adalah 16 siswa TK B di PAUD FL, Jakarta Barat yang akan dibagi ke dalam dua kelompok dengan jumlah masing-masing 8 siswa. Adapun kriteria partisipan adalah siswa aktif TK B di PAUD FL, dengan range usia 5-6 tahun. Teknik pengambilan sampel dalam penelitian ini menggunakan purposive sampling dengan pertimbangan dalam hal kemudahan memperoleh sampel siswa TK B serta PAUD yang belum tahu dan belum pernah melaksanakan metode tunjukkan dan ceritakan sebagai metode pembelajaran di kelas.

\section{Pengukuran}

Instrumen pengukuran yang digunakan dalam penelitian ini berupa tes kesiapan membaca yang diadaptasi oleh peneliti dari alat ukur Reading Readiness Assessment - Learning Disabilities Association of Alberta. Tes kesiapan membaca dibagi menjadi tiga subtes, yaitu Kosakata Ekspresif (15 butir), Identifikasi Bunyi Huruf (24 butir) dan Mendeteksi Akhiran Suku Kata (10 butir). Masing-masing butir tes kesiapan membaca berupa benar/salah, sehingga subjek akan mendapatkan skor 1 jika subjek menjawab dengan benar dan skor 0 jika subjek menjawab salah.

Tes kesiapan membaca yang diadaptasi oleh peneliti telah melalui validitas expert judgment dari 3 pakar yang merupakan dosen Fakultas Psikologi Universitas Tarumanagara. Peneliti mendapatkan nilai validitas sebesar 0.83-1.00 untuk subtes Kosakata Ekspresif dan hasil sebesar 0.91-1.00 untuk subtes Mendeteksi Akhiran Suku Kata. Hal ini menunjukkan bahwa semua butir berada pada skor di atas 0.66 , sehingga tidak perlu dilakukan eliminasi butir.

Setelah melakukan validitas expert judgment, maka peneliti melakukan uji coba alat ukur tes kesiapan membaca di salah satu PAUD di Jakarta Barat dengan jumlah partisipan sebanyak 25 anak TK, untuk melihat nilai validitas dan reliabilitasnya.

Uji validitas dan reliabilitas instrumen dengan menggunakan konsistensi internal (internal consistency) dengan melihat nilai koefisien $\alpha$ dan Corrected Item Total Correlation sebagai daya beda butir. Hasil koefisien $\alpha$ untuk subtes Kosakata Ekspresif sebesar 0.926. Sementara hasil koefisien $\alpha$ untuk subtes Mendeteksi Akhiran Suku Kata sebesar 0.802. Wells \& Wollack (dalam Azwar, 2012) menyatakan bahwa koefisien konsistensi internal paling tidak setinggi 0.80 atau 0.85. Berdasarkan penjelasan di atas, maka tes kesiapan membaca telah reliabel.

Azwar (2012) menyatakan bahwa batas nilai koefisien daya beda butir lebih besar atau sama dengan 0.3 agar butir tidak dieliminasi. Skor corrected item-total correlation yang didapatkan pada subtes Kosakata Ekspresif sebesar 0.339-0.945. Sementara skor corrected item-total correlation yang didapatkan pada subtes Mendeteksi Akhiran Suku Kata sebesar 0.359-0.647. Hal ini menunjukkan bahwa skor uji beda daya butir berada di atas 0.3 , sehingga tidak ada butir yang digugurkan. Berikut adalah blue print alat ukur kesiapan membaca yang akan peneliti gunakan dalam penelitian ini. 


\section{Tabel 1}

Blueprint Tes Kesiapan Membaca

\begin{tabular}{clc}
\hline \multicolumn{1}{c}{ Subtes } & \multicolumn{1}{c}{ Deskripsi } \\
\hline Kosakata Ekspresif & $\begin{array}{l}\text { Mengukur keterampilan dalam } \\
\text { menyebutkan nama suatu benda } \\
\text { yang tersedia dalam bentuk } \\
\text { gambar. }\end{array}$ \\
$\begin{array}{l}\text { Identifikasi Bunyi } \\
\text { Huruf }\end{array}$ & $\begin{array}{l}\text { Mengukur keterampilan } \\
\text { identifikasi huruf atau alfabet. }\end{array}$ \\
Mendeteksi Akhiran \\
Suku Kata
\end{tabular}

Selain menggunakan alat ukur kesiapan membaca, peneliti juga menggunakan alat ukur Expressive Vocabulary Test yang dibuat oleh Kathleen T. Williams, PhD, untuk melihat jumlah kata dan jumlah kosakata yang dihasilkan oleh anak pada saat pre dan post-test. Tes ini terdiri dari $19 \mathrm{kata}$, yaitu: mata, gajah, kentang, rumah, hidung, buah, hujan, buku lapar, baju, cabai, keluarga, kompor, musuh, kertas, berlian, tentara, turis dan kejahatan. Pada tes ini, anak diminta untuk merumuskan pemikirannya terhadap suatu stimulus kata yang diekspresikan melalui kombinasi kata yang sesuai. Pemberian alat ukur Expressive Vocabulary Test tidak dibatasi waktu tetapi kurang lebih membutuhkan rata-rata waktu 10 hingga 20 menit.

Metode tunjukkan dan ceritakan dilakukan selama delapan sesi dengan durasi 45-60 menit, dengan menyesuaikan pada tema pembelajaran di PAUD FL. PAUD FL dipilih karena adanya keluhan dari orangtua yang disampaikan kepada guru terkait dengan sesi belajar membaca yang membosankan bagi anak karena anak difokuskan untuk membaca dan menyalin kata yang disebutkan oleh guru.

Sesi pertama hingga sesi ke-empat, metode tunjukkan dan ceritakan dilakukan dengan memberikan gambar saja tanpa adanya huruf yang menerangkan gambar tersebut. Sementara sesi ke-lima hingga ke-delapan dilakukan dengan memberikan gambar serta huruf yang menjelaskan gambar tersebut. Adapun delapan tema yang diangkat pada metode tunjukkan dan ceritakan antara lain: kebersihan diri, mainan kesukaan, keluargaku, profesi atau cita-citaku, hewan darat, hewan air, hewan udara dan diriku. 


\section{HASIL DAN PEMBAHASAN}

Uji hipotesis bahwa metode tunjukkan dan ceritakan efektif terhadap kesiapan membaca anak TK di tolak. Uji hipotesis dilakukan dengan menggunakan software SPSS Versi 23. Peneliti menguji hipotesis dengan menggunakan uji beda (independent t-test) yang membandingkan gain score kesiapan membaca pada dua kelompok (KE dan KK). Gain score didapatkan dengan cara mencari selisih antara skor total post-test dengan skor total pre-test kesiapan membaca. Berikut adalah tabel hasil uji beda gain score pre dan post-test kesiapan membaca.

\section{Tabel 2}

Hasil Uji Beda Gain Score Tes Kesiapan Membaca

\begin{tabular}{cccccc}
\hline KE/KK & $\mathbf{N}$ & Mean & Std. Deviasi & t & p \\
\hline KK & 8 & 6.63 & 5.502 & \multirow{2}{*}{1.678} & \multirow{2}{*}{0.114} \\
KE & 8 & 11.38 & 5.755 & & \\
\hline
\end{tabular}

Keterangan:

KK $\mathrm{K}$ Kelompok Kontrol

KE $\mathrm{K}$ Kelompok Eksperimen

Hasil uji beda menunjukkan mean gain score pada KK sebesar 6.63 dan mean KE sebesar 11.38, dengan standar deviasi pada KK sebesar 5.502 dan standar deviasi pada KE sebesar 5.755. Hasil uji beda (independent $t$-test) gain score pada kedua kelompok menunjukkan nilai $\mathrm{t}=1.678$ dengan signifikansi $\mathrm{p}=0.114$ ( $>0.05)$. Berdasarkan hasil uji beda gain score pada kedua kelompok, maka dapat disimpulkan bahwa metode tunjukkan dan ceritakan tidak terbukti untuk meningkatkan kesiapan membaca anak. Sehingga, hasil dari uji dari penelitian ini adalah metode tunjukkan dan ceritakan tidak efektif terhadap kesiapan membaca anak Taman Kanak-Kanak (TK).

Peneliti melakukan uji beda (independent t-test) dengan menggunakan alat ukur Expressive Vocabulary Test. Peneliti melakukan analisis kualitatif berdasarkan verbatim dari respon partisipan pada masing-masing butir Expressive Vocabulary Test, lalu menjadikan analisis kualitatif tersebut menjadi kuantitatif berdasarkan kata yang diucapkan oleh partisipan. Peneliti melihat jumlah kata dan jumlah kosakata yang diucapkan partisipan dari masing-masing butir Expressive Vocabulary Test. Jumlah kata dihitung dengan menjumlahkan keseluruhan kata yang diucapkan oleh partisipan, sementara jumlah kosakata dihitung dengan cara melakukan pengurangan antara jumlah kata dengan kosakata yang telah diucapkan lebih dari satu kali oleh partisipan. Berikut adalah tabel hasil uji beda gain score pre dan post-test Expressive Vocabulary Test.

\section{Tabel 3}

Hasil Uji Beda Gain Score Tes Kesiapan Membaca

\begin{tabular}{cccccc}
\hline KE/KK & $\mathbf{N}$ & Mean & Std. Deviasi & t & p \\
\hline KK & 8 & 17.88 & 11.544 & \multirow{2}{*}{4.913} & \multirow{2}{*}{0.002} \\
KE & 8 & 154.75 & 77.946 & & \\
\hline
\end{tabular}

Mean gain score pada KK sebesar 17.88 dan mean KE sebesar 154.75, dengan standar deviasi pada KK sebesar 11.544 dan standar deviasi pada KE sebesar 77.946. Hasil uji beda (independent $t$-test) gain score pada kedua kelompok menunjukkan nilai $\mathrm{t}=4.913$ dengan signifikansi $\mathrm{p}=0.002$ $(\mathrm{p}<0.05)$. Berdasarkan hasil uji beda gain score pada kedua kelompok, maka dapat disimpulkan bahwa metode tunjukkan dan ceritakan mampu meningkatkan kosakata anak dalam merumuskan pemikirannya yang diekspresikan melalui kombinasi kata yang sesuai. 
Berdasarkan hasil uji beda di atas, maka penerapan metode tunjukkan dan ceritakan dikatakan tidak efektif terhadap kesiapan membaca anak TK karena dibutuhkan penelitian jangka panjang atau longitudinal untuk melihat peningkatan kosakata dan tata bahasa anak yang akan sejalan dengan peningkatan kemampuan membaca anak pada jenjang pendidikan berikutnya. Hal ini sejalan dengan hasil penelitian Loban (dalam Robbins, 1978) yang menyatakan bahwa siswa yang memiliki kemampuan bahasa lisan yang tinggi akan menunjukkan peringkat yang tinggi juga dalam membaca pada tahun-tahun berikutnya. Chang dan Chien-ju (2006) menemukan bahwa anak-anak yang memiliki keterampilan narasi yang baik saat pra-sekolah akan menunjukkan hasil yang lebih baik lagi dalam pemahaman membaca dan tugas bahasa di Sekolah Dasar. Chang dan Chien-ju (2006) menyimpulkan bahwa hubungan yang berkelanjutan dan saling terkait antara narasi lisan di awal pendidikan dengan kemampuan membaca di jenjang pendidikan berikutnya terbukti tidak hanya terjadi pada anak-anak berbahasa Inggris, tetapi juga pada anak berbahasa Mandarin.

Namun di sisi lain, metode tunjukkan dan ceritakan mampu meningkatkan kemampuan bahasa lisan anak, yaitu berbicara. Hal ini tercermin dalam hasil Expressive Vocabulary Test yang peneliti berikan saat pre-test dan post-test bersamaan dengan pemberian tes kesiapan membaca. Hal ini sejalan dengan hasil penelitian dari Endarweni (2014); Bangun (2018); Suryaningsih (2017) menunjukkan bahwa metode tunjukkan dan ceritakan terbukti mampu meningkatkan kemampuan berbicara lisan siswa.

Kemampuan bahasa kedua yang nampak pada pelaksanaan metode tunjukkan dan ceritakan, yaitu berbicara. Berbicara termasuk dalam keterampilan bahasa lisan yang menjadi dasar bagi pemahaman membaca di kemudian hari (Cabell et al., 2009). Keterampilan bahasa lisan dapat diwujudkan dalam bentuk narasi yang menceritakan suatu peristiwa. Masa pra sekolah dan tahun awal sekolah bercerita seharusnya ditetapkan sebagai komponen penting yang dapat membantu anak dalam membaca pada jenjang pendidikan berikutnya (Anderson et al., 2003). Bercerita di TK telah terbukti menjadi prediktor yang lebih besar dalam keberhasilan membaca di kelas dua SD (Fazio et al., 1996).

\section{KESIMPULAN DAN SARAN}

Hasil analisis data menunjukkan bahwa metode tunjukkan dan ceritakan tidak efektif terhadap kesiapan membaca anak TK. Namun penelitian ini menemukan bahwa metode tunjukkan dan ceritakan efektif untuk meningkatkan kosakata anak yang diwujudkan dalam kombinasi kata yang diucapkan anak dalam mengartikan atau menjelaskan suatu kata.

Dengan adanya penelitian ini maka metode tunjukkan dan ceritakan dapat direkomendasikan kepada PAUD sebagai salah satu metode pelajaran untuk mengembangkan keterampilan bahasa lisan. Penerapan metode tunjukkan dan ceritakan terbukti efektif untuk meningkatkan kosakata anak, sehingga guru dapat menerapkan metode ini sebagai model pembelajaran di kelas. Selain meningkatkan kosakata anak, metode ini juga dapat menjadi salah satu cara untuk membuat anak menjadi percaya diri saat maju dan berbicara di depan umum.

Selain itu, peneliti berikutnya dapat mengembangkan Expressive Vocabulary Test, lalu menguji validitas dan reliabilitas serta pembuatan norma Expressive Vocabulary Test dalam bahasa Indonesia. Sehingga Expressive Vocabulary Test dapat digunakan sebagai alat ukur untuk melihat kemampuan berbahasa lisan pada anak usia dini. Peneliti berikutnya juga dapat melakukan penelitian yang bersifat jangka panjang atau longitudinal untuk mendapatkan hasil penerapan 
metode tunjukkan dan ceritakan terhadap kemampuan membaca anak pada jenjang pendidikan berikutnya.

\section{Ucapan Terima Kasih}

Terima kasih kepala sekolah serta seluruh guru di PAUD FL yang telah mengijinkan peneliti untuk melaksanakan metode tunjukkan dan ceritakan di kelas TK B.

\section{REFERENSI}

Anderson, J., Anderson, A., Lynch, J., \& Shapiro, J. (2003). Storybook reading in a multicultural society: Critical perspectives. In A. van Kleeck, S. A. Stahl, \& E. Bauer (Eds.), On reading to children: Parents and teachers (pp. 203-230). Erlbaum.

Azwar, S. (2012). Reliabilitas dan validitas. Pustaka Pelajar.

Bangun, B. K. (2018). Improving students' speaking skill by using show and tell method: A classroom action research. International Journal of Language Teaching and Education, 2(1), 41-48. https://doi.org/10.22437/ijolte.v2i1.4517

Bowyer-Crane, C., Snowling, M. J., Duff, F. J., Fieldsend, E., Carroll, J. M., Miles, J., \& Hulme, C. (2008). Improving early language and literacy skills: Differential effects of an oral language versus a phonology with reading intervention. Journal of Child Psychology and Psychiatry, 49(4), 422-432. https://doi.org/10.1111/j.1469-7610.2007.01849.x

Cabell, S. Q., Justice, L. M., Zucker, T., \& Kilday, C. R. (2009). Validity of teacher report for assessing the emergent literacy skills of at-risk preschoolers. Language Speech and Hearing Services in Schools, 40(2), 161-73.

Chang, Chien-ju (2006). Linking early narrative skill to later language and reading ability in Mandarin-speaking children: A longitudinal study over eight years. Narrative Inquiry, 16(2), 275-293. https://doi.org/10.1075/ni.16.2.04cha

Dhieni, N., Fridani, L., Yarmi, G., \& Kusniaty, N. (2009). Metode pengembangan bahasa. Universitas Terbuka.

Dickinson, D.K., \& McCabe, A. (2001). Bringing it all together: The multiple origins, skills, and environmental supports of early literacy. Learning Disabilities Research and Practice, 16, 186-202.

Eliza, D. (2014). Reading readiness of kindergarten students of at-taqwa mosque east Jakarta. Indonesian Journal of Early Childhood Education Studies, 3(1), 1-6.

Endarweni, Y. (2014). Implementing the show and tell technique to improve the speaking skill of grade VIII students at SMP Pembaharuan Purworejo. [Thesis, Universitas Negeri Yogyakarta]. http://eprints.uny.ac.id/19865/pdf

Fazio, B. B., Naremore, R. C., \& Connell, P. J. (1996). Tracking children from poverty at risk for specific language impairment: A 3-year longitudinal study. Journal of Speech and Hearing Research, 39(3), 611-624. https://doi.org/10.1044/jshr.3903.611

Juwita, T., \& Tasu'ah, N. (2015). Bead board letter media effectiveness as the introduction concept of reading in children aged 5-6 Years. Indonesian Journal of Early Childhood Education Studies, 4(1), 46-50. https://doi.org/10.15294/ijeces.v4i1.9453

Karweit, N. (1989). The effects of a story-reading program on the vocabulary and story comprehension skills of disadvantaged prekindergarten and kindergarten students. Early Education and Development, 1(2), 105-114. https://doi.org/10.1207/s15566935eed0102_2

Kementerian Pendidikan dan Kebudayaan. (2015). Kerangka dasar dan struktur kurikulum 2013 pendidikan anak usia dini. Direktorat Pembinaan Pendidikan Anak Usia Dini.

Mason, J. M. (1977). Questioning the notion of independent processing stages in reading. Journal of Educational Psychology, 69(3), 288-297. https://doi:10.1037/0022-0663.69.3.288 
McNamara, J. K., Scissons, M., \& Simonot, S. (2004). Should we "redshirt" in kindergarten? A study of the effect of age on kindergarteners' reading readiness. Alberta Journal of Education Research, 50, 128-140.

Morrison, G, S. (2008). Fundamentals of early childhood education (7th ed.). Pearson Education.

Robbins, G. E. (1978). A survey of reading-readiness skills and their application to the late reader [Disertasi dan Thesis]. PDX Scholar.

Slavin, R. E. (2009). Educational psychology: Theory and practice (9th ed.). Pearson Education.

Suryaningsih. (2017). Pengaruh metode pembelajaran show and tell terhadap keterampilan berbicara siswa kelas IV SD Muhammadiyah Condongcatur. [Skripsi, Universitas Islam Negeri Sunan Kalijaga].

Susanto, A. (2011). Perkembangan anak usia dini. Kencana Prenada Media Group.

Triatri, S. (2009). Perkembangan pemahaman bacaan. Dalam: Dari anak sampai usia lanjut. PT BPK Gunung Mulia. 